\title{
THE INFLUENCE OF EDUCATIONAL LEVEL, WORK EXPERIENCE AND COMPREHENSION OF ACCOUNTING INFORMATION SYSTEM ON FINANCIAL REPORT QUALITY
}

\begin{abstract}
This study is conducted to: 1 ) test and analyze the influence of educational level on financial report quality; 2) test and analyze the influence of work experience on financial report quality; 3 ) test and analyze the influence of accounting information system on financial report quality. Population in this study is all employees employed in district financial department in Surakarta with the sample amounted of 30 employees. Data analysis method is multi-linear regression. Results of hypothesis analysis showed that work experience $\left(\mathrm{H}_{2}\right)$ and accounting information system comprehension $\left(\mathrm{H}_{3}\right)$ have influence on financial report quality, and the educational level $\left(\mathrm{H}_{1}\right)$ variable has no influence on financial report quality.
\end{abstract}

Keywords: Educational level, work experience, accounting information system comprehension, financial report quality.

\section{INTRODUCTION}

Financial report is a procedure or final result of an accounting activities to provide information to the company or related institutions on profitability, debts and assets of the company. Therefore, to support high qualified and good financial report, it is necessary for skilled, competent human resources available for the company for good and qualified financial report. An accountably good and qualitied financial report is those presenting correct, honest, reliable, comparably relevant and conceivable information. A qualified financial report is very important because of its use as the basics in decision making.

Then to manage a good and qualified regional financial, the regent/city governments must have good and competent human resources, those equipped with accounting-based education level. Regional government will be fail to provide financial report if from the beginning, it doesn't implement and comprehend the accounting logics with the standards applied by the government (Djauzak, 2014). Educational level is influencing human resource capacity as one of the key element in the presentation and utilization of governmental financial report. Besides, to obtain good financial report quality, it needs for work experience. Work experience is a skill or expertise of an officer obtained in working times at other location, so that an officer can be an expert and comprehendable on their work and duties. Besides, other factor in making a good and accountable financial report is the accounting information system. In here, accounting information system is the instrument utilized by the management in an organization to provide an added value for competitive advantage and reliable internal information (Mulyadi, 2011).

Studies analyzing the influence of education level, work experience and accounting information system (SIA) comprehension on financial report quality, among the others, is Priyatna (2015) who found empirical evidence that the education level is not influencing the financial report quality of Regional government and 
work experience has negative influence on financial report quality of Regional government. Rianisanti (2017) provided empirical finding that the utilization of accounting information system of regional financial has no influence on financial report quality of regional government, while the capacity of human resource has influence on the financial report quality of regional government. Maryatun (2017) showed that the level of education has positive influence on financial report quality. Work experience also has positive influence on financial report quality, and the comprehension of accounting information system did the same on financial report quality. Therefore, the financial report can improve the quality and accountability of the financial report for the availability of good financial report in timely manner.

Based on the abovementioned description, the author takes "The Influence of Education Level, Work Experience and Comprehension of Accounting Information System on Financial Report Quality."

\section{SKELETON TEORITIS AND DEVELOPMENT HYPOTHESES}

The Commission of Financial management Improvement in the Indonesian government Regulation No. 8 year of 2006 on Financial Report and governmental Institution Performance explained that financial report is a form of responsibility of public financial management in a certain period of time. According to the Government Regulation 71 Year of 2010 on Standards of Governmental Accounting, financial report is arranged to provide relevant information on financial state and all transaction administered by a reporting entity during one reporting period.

Education is a word frequently found in our daily life. But it is sometime we has insufficient understanding on the term education itself. Education is a learning process to compile and improve knowledge. Level of education or frequently referred education strata is determined on base of student's improvement level. The objectives to be achieved and the competency to be crafted in certain sector (specialties) based on its educational backgrounds will improve knowledge in related sector. Education grows competency to sort and select information and shape the relevant information required in decision making (Libby, 1995). In further development, specifically in Department of National Education, this sustainable education has been made to be the facility for the graduates of Paket A and Paket B Learning Group to hold learning activities according to their learning need in effort to obtain or improve competencies for independence.

Work experience is a primary capital to enter an occupational sector. Work experience can be appreciated more than education level (Siswanto, 1987). Work experience is sufficiently important factor in workforce provision. For the implementation of workforce provision, it is necessary to bconsider and determine the quality of the required workforce. One of the work requirement is work experience. A company will tend to hire those with work experience rather than inexperienced workforces because they are expected to have more abilities in work implementation (Marttoyo, 1987).

Accounting information system is a set of resources, like human, instruments, manufacture, managed to transform data into important information in effort to support decision making. Information system is similar with computer-based, contains hardwares and softwares, and also the human to transform the data into information. Bodnar (2008) stated that: "An accounting information system is a computer-based system 
designed to transform accounting data into information." Basically, accounting information system presented in form of financial report can be used as the basic of decisional making related with financial and non-financial aspects of a company.

According to several studies by Romdhoni (2017), it found that education level has positive relation with financial report quality. According to Hartati (2016), she found that work experience has strong relation with financial report. Studies by Maryatun (2017) suggested that the comprehension of accounting information system has positive influence on financial report quality.

Study hypothesis by Maryatun was to test the quality of investigation results on educational backgrounds. In this study, it re-tested the influence of education level on financial report quality in OPD which was supported, so that this study takes as follows:

\section{H1: Education level has positive influence on financial report quality.}

Hypothesis by Muzahid (2014) tested the quality of investigation results on work experience. In this study, it re-tested the influence of work experience on the quality of financial report in OPD, for the hypothetic result as follows:

\section{H2: Work experience has positive influence on quality of financial report.}

Alfian (2015) hypothesized on the quality of financial report and management of SIA comprehension. Results of the study showed that SIA comprehension has its influence on financial report quality in OPD, so that it can be hypothesized as follows:

\section{H3: The comprehension of accounting information system has positive influence on quality of financial report.}

\section{RESEARCH METHOD}

Type of this study is descriptive quantitative, in which describing the influence of education level, work experience and comprehension of accounting information system on quality of financial report. Source of data is primary data. It is from the respondents collected through questionnaire-based survey. Questionnaire is a data collection instrument by providing a seet of written questions to respondents to be filled.

Population in this study is all employees worked in 5 districts' financial department in Surakarta, and samples to be taken are the government officer served in financial department, consisted of district secretary, the head of financial department, district treasurer and staffs of financial department. Each district has its 6 officers directly related with financial report to compile of 30 employees from all 5 districts in Surakarta. Method in this study was saturated sample (census) in which all populations are the sample.

\section{RESULTS AND DISCUSSION}

Result of validity test based on respective variable of education level (X1), work experience (X2), comprehension of accounting information system (X3) and financial report quality $(Y)$ with its $r$ count more than $r$ table $\left(r_{\text {count }}>r_{\text {table }}\right)$ and significance value of $<0.05$, it conclude that all variables are valid. 
Result of reliability test based on respective variable of all statement item related with independent variables (education level, work experience, comprehension of accounting information system) can be considered reliable, because all variables have their cronbach's alfa value of $>0.70$.

Result of data-based normality test is normally distributed because the unstandardized residual value has its significance value of $>0.05$.

Result of heteroschedacity test with Gletser method showed that each variable is in homoschedacity criteria, except for work experience. It means that residual significance value for education level and SIA comprehension are more than significance level of 0.05 or higher than confidential level of $5 \%$, and work experience residual is less than significance level of 0.05 . It can be concluded that regression model in this study contains homoschedacity except for work experience.

Result of multicolinearity test showed that all variables have no multicolinearity deviation because all variables have their tolerance value of $>0.1$ and VIF value of $<10$.

Result of autocorrelation test using Durbin Watson (d) method showed that $d$ value of 1.908, while the upper bound (du) and lower bound ( $d l)$ are 1.213 and 1.649, respectively. Based on the criteria that $d$ value is in between $\mathrm{dU}<\mathrm{d}<4-\mathrm{dU}$, it can be concluded that there is no autocorrelation.

Result of multilinear regression model using SPSS obtained the following regression equation:

$$
\mathrm{Y}=3,431-0,124 \times 1+0,698 \times 2+0,390 \times 3
$$

\section{The obtained regression equation can be interpreted as follows:}

Constant value (a) of 3.431 means if the education level variable (X1), work experience (X2), comprehension of accounting information system (X3) are considered constant, then the quality of financial report is positive.

$\beta_{1}$ of -0.124 means that if other independent variables are constant and $X 1$ increases of $1 \%$, then the quality of financial report $(Y)$ will decrease of 0.124 . Negative-valued coefficient means there is negative relation between $\mathrm{X} 1$ and $\mathrm{Y}$, the higher $\mathrm{X} 1$, the lower $\mathrm{Y}$.

$\beta_{2}$ of 0.698 means that if other independent variables are constant and $X 2$ increases of $1 \%$, then quality of financial report $(Y)$ will increase of 0.698 . Positive-valued coefficient means there is positive relation between $\mathrm{X} 2$ and $\mathrm{Y}$, the higher $\mathrm{X} 2$, the better $\mathrm{Y}$.

$\beta_{3}$ of 0.390 means that if other independent variables are constant and $X 3$ increases of $1 \%$, then quality of financial report $(Y)$ will increase of 0.390 . Positive-valued coefficient means there is positive relation between $\mathrm{X} 3$ and $\mathrm{Y}$, the higher $\mathrm{X} 3$, the better $\mathrm{Y}$.

Result of $F$ test using SPSS 2.1 obtained that $F_{\text {count }}$ value is 15.202 and Sig. 0.000 . It is larger in comparison with $\mathrm{F}_{\text {table }}$ of 2.922 and significance value of $<0.05$. It is so that the regression model in this study is feasible. And it shows that the model is meeting the feasibility test.

Result of $t$-test for education level variable is $t_{\text {count }}$ of $-0.985<t_{\text {table }}$ of 0.706 with probability value of 0.334 , which means larger than 0.05 thus $\mathrm{H} 1$ is rejected. It means that education level is not influencing the quality of financial report. Result of t-test analysis for work experience variable is $t_{\text {count }}$ of $4.394>t_{\text {table }}$ of 0.706 with probability value of 0.000 means that less than 0.05 thus $\mathrm{H} 2$ is accepted. It means that work experience is 
influencing the quality of financial report. Result of t-test analysis for comprehension of accounting information system variable is $\mathrm{t}_{\text {count }}$ of $2.515>\mathrm{t}_{\text {table }}$ of 0.706 with probability value of 0.018 means that less than 0.05 thus $\mathrm{H} 3$ is accepted. It means that the comprehension of accounting information system is influencing the quality of financial report.

Result of determination coefficient calculation can be known that the dependent variable can be explained of $59.5 \%$ by independent variable (education level, work experience and comprehension of accounting information system). It shown from the Adjusted R Square value of 0.595. While for dependen variable financial report quality of $40.5 \%$ is influenced by other variable beyond this study. The Adjusted $R$ Square value is less than thos obtained by Maryatun (2017), where the influence of education level, work experience and comprehension of accounting information system on quality of financial report of $89 \%$ due to regression coefficient in independent variable has negative value so that the determination coefficient in this study is low.

\section{Education Level has No Positive Influence on Quality of Financial Report}

Based on the results of multilinear regression analysis, the regression coefficient value is negative. It shows that there is conversed directional relation between education level and quality of regional government financial report. It shown by the value of $t_{\text {count }}$ of -0.985 and significance value of 0.334 . because of the value of $\mathrm{t}_{\text {count }}<\mathrm{t}_{\text {table }}(-0.985<0.706)$, then $\mathrm{H} 1$ is rejected, meaning that the education level has no significant influence on quality of regional government financial report.

Result of this study indicates that education level variable has no influence on the quality of financial report due to in District's Organisasi Perangkat Daerah (OPD) in Surakarta has been implementing system Informasi Manajemen Daerah (SIMDA), then all employees in financial department with their varied educational level can easily arrange qualified financial report.

Work Experience has Positive Influence on Quality of Financial Report

Based on the result of multi-linear regression analysis, there can be observed that the value of regression coefficient is positive. It shows that there is parallel relation between work experience providing positive influence on quality of regional government financial report. It shown by $t_{\text {count }}$ value of 4.394 and significance value of 0.000 . Due to $t_{\text {count }}>t_{\text {table }}(4.394>0.706)$, then $\mathrm{H} 2$ is supported meaning that work experience has its influence on quality of financial report.

Result of this study indicates that work experience in compiling financial report can be shaped as knowledge and information, and also will improve the concerned officer in their capacities to lessen error that might be occurred.

\section{Comprehension of Accounting Information System has Positive Influence on Quality of Financial Re- port}

Based on result of multilinear regression analysis, the regression coefficient value is positive. It shows that there is parallel relation between the comprehension of accounting information system on quality of regional government financial report. It shown by $t_{\text {count }}$ value of 2.515 and significance value of 0.018 . Due to $t_{\text {count }}>t_{\text {table }}$ 
(2.515 > 0.706), then $\mathrm{H} 3$ is supported meaning that the comprehension of accounting information system has influence on quality of financial report.

Result of this study indicates that by the utilization of software and hardare in the Organisasi Perangkat Daerah (OPD) in districts of Suraarta can assist the officers to provide financial report in timely manner and also can transform the data to be relevan and accountable information.

\section{CLOSURE}

This studi is aimed to analyse whether the influence of education level, work experience and comprehension on accounting information system existed on the quality of financial report. Type of this study is quantitative research. Sample in this study is 30 respondents. Analysis method using multilinear regression analysis. Result of this study indicates that education level variable has no influence on the quality of financial report. It is due to in Organisasi Perangkat Daerah (OPD) districts in Surakarta has been implementing system Informasi Manajemen Daerah (SIMDA) by which all officer in financial department with varied level of education can easily arrange qualified financial report. Work experience has positive influence on quality of financial report on which their experience can form knowledge and information, and also can improve officers' ability in lessening error might be occurred. Comprehension on accounting information system has its influence on quality of financial report by the utilization of software and hadware in the Organisasi Perangkat Daerah (OPD) districts in Surakarta to assist the officers to meet the financial reporting in timely manner and transform the data to be relevant and accountable information.

This study has several limitations, they are: a) the scope of study is limited on Organisasi Perangkat Daerah (OPD) Districts of Suraarta; b) this study is only include three independent variable to know the influence on quality of financial report which are education level, work experience and comprehension of accounting information (SIA), which factually, there are many independent variables influencing the quality of regional government financial report to be included.

Suggestions for future study are: a) result of this study can be generalized not only in Surakarta city, but it can be expanded to all cities in Indonesia; b) for further study, it can expand the independent variable beyond education level, work experiment and comprehension on accounting information system to be reference in holding more comprehensive advanced studies 


\section{REFERENCES}

Afiah, NA 2014. 'Factors Influencing The Quality Of Financial Reporting And Its Implications On Good Government Governance (Research On Local Government Indonesia)', internasional journal of bisinees, economics and law , ISSN 2289-1552 Vol.5, Issue 1 (Dec).

Alfian, M. 2015. 'Faktors Supporting Implementation SIMDA Effect On Quality Of Financial Reporting On SKPD District Kulon Progo', Journal Of Economics And Business, ISSN 1979-6471. VOL. XVIII, NO. 3. Universitas Sebelas Maret,Surakarta. Indonesia.

Bodnar, GH, 2008, Sistem Informasi Akuntansi. In y. a. amir abadi, Sistem Informasi Akuntansi. Jakarta: Salemba Empat.

Desster, G 2012, Manajemen Sumber Daya Manusia. Yogyakarta: Andi.

Djauzak, A 2014, Pengaruh Mutu Pendidikan Sebagai Sarana Pembangunan Bangsa. Jakarta: Balai Pustaka.

Ghozali, I 2011, Aplikasi Analisis Multivariate Dengen Program SPSS. Semarang: Universitas Diponogoro.

Hartati, 2016,' Pengaruh Pendidikan, Pelatihan Teknis Keuangan Dan Pengalaman Kerja Terhadap Kualitas Laporan Keuangan (Studi Pada Skpd Provinsi Sulawesi Tengah), Journal Katalogis , Universitas Tadulaka. ISSN: 2302-2019 Volume 4, Nomor 9, e.

Libby, RD 1995,' Modeling the determinant of audit expertise', Accounting, Organization and society journal , Vol.

$18,425-450$.

Manulang, 1984, Manajemen Personalia. Jakarta: Ghalia Indonesia.

Martoyo, S 1987, Manajemen Sumber Daya Manusia. singapore: BPFE.

Maryatun., 2017,'Pengaruh Tingkat Pendidikan, Pengalaman Kerja dan Pemahaman Sistem Informasi Akuntansi

Terhadap Kualitas Laporan Keuangan (Studi Kasus pada Organisasi Perangkat Daerah Kabupaten Boyolali)', Universitas Islam Batik Surakarta .

Mulyadi. (2012). Akuntansi Biaya. yogyakarta: STIM YKPN.

Mulyadi. (2011). Sistem Akuntansi. Jakarta: Salemba Empat.

Muzahid, M 2014,'Pengaruh Tingkat Pendidikan, Kualitas Pelatihan,Dan Lama Pengalaman Kerja Pegawai Terhadap Kualitas Laporan Keuangan Satuan Kerja Perangkat Daerah (SKPD) Di Kabupaten Aceh Utara', jurnal Akuntansi , Politeknik Negeri Lhokseumawe.ISSN 2337-4314 Vol. 2, No. 2.

Nugraha, TK 2015, 'Pengaruh Latar Belakang Pendidikan, Pengalaman Kerja, Kompetensi Dan Independensi Aparat Pengawas Intern Pemerintah (Apip) Terhadap Kualitas Hasil Pemerisaan (Studi Empiris Pada Jaksa Agung Muda Bidang Pengawasan kejaksaan Agung Republik Indonesia', Jurnal Tekun, Universitas Teknologi Yogyakarta, Vol. 06 , No. 02.

Priyatna, BH 2015. Pengaruh Pemahaman Akuntansi, Tingkat Pendidikan Dan Pengalaman Kerja Pejabat Penatausahaan Keuangan Terhadap Kualitas Laporan Keuangan Pemerintah Daerah. Universitas Sebelas Maret, Surakarta.

Ranupandojo, H. d. (1984). Manajemen Personalia, Edisi III ,Vol. III. Yogyakarta: BPFE. 
Rianisanti, MD 2017, Pemanfaatan Sistem Informasi Akuntansi Keuangan Daerah Dan Kapasitas Sumber Daya Manusia Terhadap Kualitas Laporan Keuangan Pemerintah Derah Dengan Sistem Pengendalian Intern Sebagai Variabel Moderating(Studi Pada Skpd Kabupaten Klaten), Tesis. Institut Agama Islam Negeri, Surakarta.

Romdhoni, RF 2017, Pengaruh Tingkat Pendidikan, Pengalaman, Faktor Sosial Dan Pengetahuan Akuntansi Terhadap Pemanfaatan Catatan Atas Laporan Keuangan (Calk) Oleh Pengguna Laporan Keuangan Pemerintah Daerah. Tesis, Institut Agama Islam Negeri, Surakarta.

Setyowati, Ld 2014, 'Analisis Faktor Yang Mempengaruhi Kualitas Laporan Keuangan Daerah Pada Pemerintah Kota Semarang', Jurnal Proceedings SNEB .

Siswanto, B 1987, Manajemen Tenaga Kerja: Rancangan Dalam Pendayagunaan dan Pengembangan Unsur. Bandung: Sinar Baru.

Sugiyono, 2013, Metode Penelitian Kuantitatif, Kualitatif dan R \& D. Bandung: Alfabeta.

Trijoko, P 1980, Ilmu Budaya Dasar. Jakarta: Renika.

Wilkinson, J.W 2000, Accounting Information System Essential Concept and Application.

Zulkifli, 2017, Pengaruh Pemahaman Sap Berbasis Akrual, Pendidikan Dan Pelatihan, Serta Latar Belakang Pendidikan Terhadap Kinerja Penyusunan Laporan Keuangan Daerah Pada Pemerintah Kota Tanjungpinang. Tesis. Universitas Maritim Raja Ali Haji. 


\section{LAMPIRAN}

Tabel 1

Uji Reliabilitas

\begin{tabular}{lccc}
\hline \multicolumn{1}{c}{ Variabel } & $\begin{array}{c}\text { Alpha } \\
\text { Cronbach }\end{array}$ & Std & Keterangan \\
\hline Tingkat Pendidikan & 0,817 & $>0,60$ & Reliabel \\
Pengalaman Kerja & 0,834 & $>0,60$ & Reliabel \\
Pemahaman SIA & 0,791 & $>0,60$ & Reliabel \\
Kualitas Laporan Keuangan & 0,850 & $>0,60$ & Reliabel \\
\hline
\end{tabular}

Tabel 2

Hasil Uji Normalitas

\begin{tabular}{cccc}
\hline & $\begin{array}{c}\text { Unstandardized } \\
\text { Residual }\end{array}$ & Std & Keterangan \\
\hline $\mathrm{N}$ & 30 & & Data berdistribusi \\
Kolmogorov-Smirnov Z & 0,632 & $>0,05$ & Normal \\
Asymp. Sig. (2-tailed) & 0,819 & $>0,05$ & \\
\hline
\end{tabular}

\section{Tabel 3}

Hasil Uji Multikolinieritas

\begin{tabular}{lccccc}
\hline Variabel & Tolerance & Std & VIF & Std & Keterangan \\
\hline & 0,77 & $>0,10$ & 1,384 & $<10$ & $\begin{array}{c}\text { Tidak ada } \\
\text { Multikolinieritas } \\
\text { Tidak ada }\end{array}$ \\
$\begin{array}{llll}\text { Tingkat Pendidikan } \\
\begin{array}{l}\text { Pengalaman Kerja } \\
\text { Pemahaman SIA }\end{array}\end{array}$ & 0,650 & $>0,10$ & 1,538 & $<10$ & $\begin{array}{c}\text { Multikolinieritas } \\
\text { Tidak ada } \\
\text { Multikolinieritas }\end{array}$ \\
\hline
\end{tabular}


Tabel 4

Hasil Uji Heteroskedastisitas

\begin{tabular}{lrrc}
\hline \multicolumn{1}{c}{ Variabel } & \multicolumn{2}{c}{ Coeficien Standart } & Keterangan \\
\cline { 2 - 3 } & Residual & Signifikan & \\
\hline Tingkat PendidiKan & 0,282 & $>0,05$ & Tidak Heteroskedastisitas \\
Pen & & & Heteroskedastisitas \\
Pengalaman Kerja (X2) & 0,008 & $<0,05$ & Tidak Heteroskedastisitas \\
\hline
\end{tabular}

Tabel 5

Hasil Uji Autokorelasi

\begin{tabular}{cccc}
\hline Model & Std.Error of the Estimate & Durbin-Waston & Keterangan \\
\hline 1 & 3,092 & 1,908 & Tidak Terjadi \\
& & Autokorelasi \\
\hline
\end{tabular}

Tabel 6

\begin{tabular}{|c|c|c|c|}
\hline $\mathrm{N}$ & \multicolumn{2}{|c|}{ Variabel bebas (k-3) } & \multirow{3}{*}{$\begin{array}{c}\text { Disebut dalam } \\
\text { Tabel }\end{array}$} \\
\hline & $\mathrm{DL}$ & $4-\mathrm{DU}$ & \\
\hline 30 & 1,213 & 1,649 & \\
\hline
\end{tabular}

Durbin -Watson (DW Test)

Tabel 7

Hasil Uji Analisis Regresi Linier Berganda

\begin{tabular}{lc}
\hline \multicolumn{1}{c}{ Variabel } & Koefisien Regresi \\
\hline (Constant) & 3,431 \\
Tingkat Pendidikan &,- 124 \\
Pengalaman Kerja & 0,698 \\
Pemahaman SIA & 0,390 \\
\hline
\end{tabular}

Tabel 8

Hasil Uji F

\begin{tabular}{rrrrl}
\hline$F_{\text {hitung }}$ & $F_{\text {tabel }}$ & Sig. & Standar & Keterangan \\
\hline 15,202 & 2,922 & 0,000 & $<0,05$ & Model Layak \\
\hline
\end{tabular}




\section{Tabel 9}

Hasil Uji t

\begin{tabular}{cccccc}
\hline Hipotesis & ${ }^{\text {t }}$ hitung & ${ }^{t}$ tabel & Sig. & Std & Keterangan \\
\hline $\mathrm{H} 1$ & $-0,985$ & 0,706 & 0,334 & 0,05 & Ditolak \\
$\mathrm{H} 2$ & 4,394 & 0,706 & 0,000 & 0,05 & Diterima \\
$\mathrm{H} 3$ & 2,515 & 0,706 & 0,018 & 0,05 & Diterima \\
\hline
\end{tabular}

Tabel 10

Hasil Uji Koefisien Determinasi

\begin{tabular}{ccc}
\hline Model & Adjusted R Square & Kesimpulan \\
\hline 1 & 0,595 & Variabel independen dapat menjelaskan variasi \\
variabel dependen
\end{tabular}

